\title{
Troublesome Thai travels
}

\author{
Ben Christopher Reynolds, ${ }^{1}$ Sophie Hambleton, ${ }^{2}$ Dieter Friedrich Dammann, ${ }^{3}$ \\ Heather Joan Lambert, ${ }^{1}$ Marieke Emonts ${ }^{2}$
}

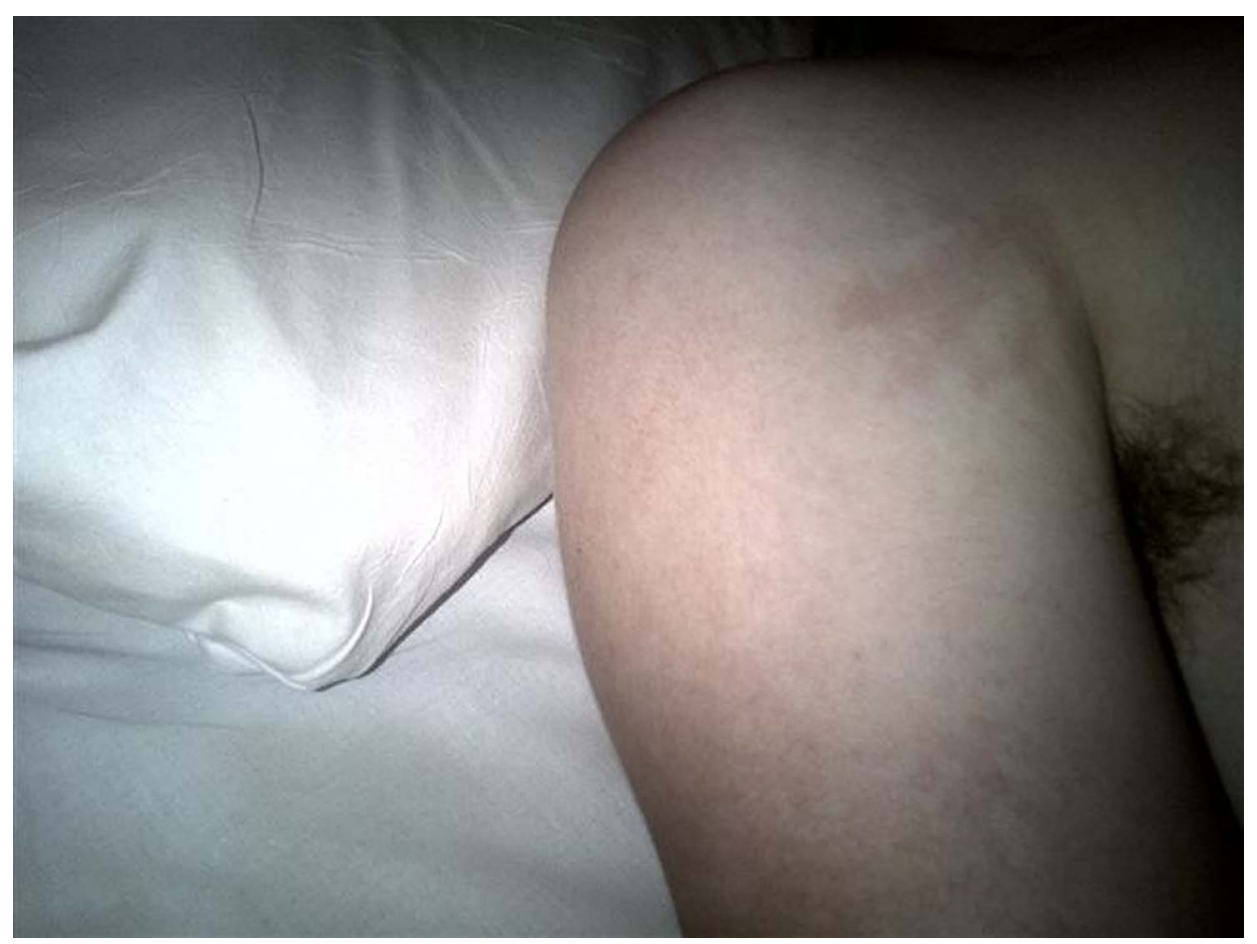

Figure 1 Macular rash on the axilla and upper arm

A previously fit and well 15 -year-old Caucasian boy presented with a week of intermittent pyrexia, nonbloody, non-mucoid diarrhoea and bilious vomiting. $\mathrm{He}$ also presented with persistent headache, general myalgia, and had episodes of rigours. He had returned 48 hours previously from a family holiday touring Thailand for three weeks with no travel towards the Vietnamese and Laos borders. All recommended pretravel immunisations had been given; antimalarial prophylaxis was not considered necessary in the areas of travel. He had travelled with both parents and his younger brother; during the trip all had engaged in open-water swimming, and eaten partly cooked meat. All family members experienced mild diarrhoea but got better. He seemed to improve but then had recurrence of large volume watery diarrhoea and myalgia for approximately 5 days prior to his return to the UK. He also had multiple insect bites, which had appeared shortly following an elephant ride. He had taken regular ibuprofen, $400 \mathrm{mg}$ three times a day, for his headaches and muscle pain over the last few days. There had been no occasions when the patient had been out of parental supervision and the parents were confident that he had not engaged in any high-risk sexual behaviour. There was no personal or family history of note.

On initial examination, he appeared unwell, was tachycardiac, not tachypnoeic and appeared clinically dehydrated though not shocked $(\sim 5 \%)$ with dry mucus membranes, cool fingers, but normal skin turgor. Initial temperature was $37.7^{\circ} \mathrm{C}$, rising to $39.4^{\circ} \mathrm{C}$ within an hour of assessment. Peripheral capillary refill time was $2 \mathrm{~s}$, blood pressure was 130/70 $\mathrm{mm} \mathrm{Hg}$. He had a migratory macular erythematous rash (figure 1) over his trunk and limbs, which was intermittent. Several small bites were noted on his legs with moderate surrounding erythema. There was also peeling erythema over the shoulders, assumed to be sunburn. He was not jaundiced, nor was there any hepatosplenomegaly. There was no pitting oedema, nor notable lymphadenopathy. The remainder of his physical examination was normal. He was relatively oliguric with an urine output of approximately $1.1 \mathrm{~mL} / \mathrm{kg} / \mathrm{h}$ in the first $24 \mathrm{~h}$ of admission. Urine was noted to be dark yellow in colour. Urinalysis demonstrated no haematuria and only mild proteinuria. Urine microscopy did not show casts or debris.

He was commenced on intravenous ceftriaxone and oral doxycycline, intravenous fluids were started, and 
he had baseline blood and urinary investigations performed. These are listed in table 1. Thick and thin films for malaria were repeatedly negative, and a chest $\mathrm{X}$-ray was unremarkable. In view of these findings, he had an abdominal ultrasound. This demonstrated normal kidneys (upper limit of size for age, but not echogenic) and a $14.5 \mathrm{~cm}$ spleen (again within the

\section{Table 1 Initial laboratory investigations}

\begin{tabular}{|c|c|}
\hline Haemoglobin & $116 \mathrm{~g} / \mathrm{L}$ \\
\hline Platelet count & $297 \times 10^{9} / \mathrm{L}$ \\
\hline Haematocrit & $0.315 \mathrm{~L} / \mathrm{L}$ \\
\hline Mean cell volume & $75.7 f \mathrm{~L}$ \\
\hline White blood cell count & $6.31 \times 10^{9} / \mathrm{L}$ \\
\hline Neutrophils & $4.91 \times 10^{9} / \mathrm{L}$ \\
\hline Lymphocytes & $0.78 \times 10^{9} / \mathrm{L}$ \\
\hline Monocytes & $0.60 \times 10^{9} / \mathrm{L}$ \\
\hline Sodium & $128 \mathrm{mmol} / \mathrm{L}$ \\
\hline Potassium & $5.0 \mathrm{mmol} / \mathrm{L}$ \\
\hline Chloride & $92 \mathrm{mmol} / \mathrm{L}$ \\
\hline Total CO2 & $16 \mathrm{mmol} / \mathrm{L}$ \\
\hline Urea & $24.1 \mathrm{mmol} / \mathrm{L}$ \\
\hline Creatinine & $597 \mu \mathrm{mol} / \mathrm{L}$ \\
\hline C-reactive protein & $146 \mathrm{mg} / \mathrm{L}$ \\
\hline Albumin & $34 \mathrm{~g} / \mathrm{L}$ \\
\hline Calcium & $2.30 \mathrm{mmol} / \mathrm{L}$ \\
\hline Phosphate & $1.36 \mathrm{mmol} / \mathrm{L}$ \\
\hline Magnesium & $0.84 \mathrm{mmol} / \mathrm{L}$ \\
\hline Bilirubin & $3 \mu \mathrm{mol} / \mathrm{L}$ \\
\hline Alkaline phosphatase & $215 U / L$ \\
\hline Alanine transaminase & $89 \mathrm{U} / \mathrm{L}$ \\
\hline Amylase & $52 \mathrm{U} / \mathrm{L}$ \\
\hline Creatine kinase & $53 \mathrm{U} / \mathrm{L}$ \\
\hline \multicolumn{2}{|l|}{ URINE } \\
\hline Sodium & $60 \mathrm{mmol} / \mathrm{L}$ \\
\hline Potassium & $14 \mathrm{mmol} / \mathrm{L}$ \\
\hline Creatinine & $5.5 \mathrm{mmol} / \mathrm{L}$ \\
\hline Protein:creatinine & $40 \mathrm{mg} / \mathrm{mmol}$ \\
\hline
\end{tabular}

upper range of normal). The liver appeared normal, and there was a tiny amount of free fluid attributed to ongoing intravenous rehydration.

Within $24 \mathrm{~h}$ following fluid administration and while various investigations were pending, he developed a significant diuresis, up to $5 \mathrm{ml} / \mathrm{kg} / \mathrm{h}$ of urine, necessitating ongoing intravenous fluids as he also continued to vomit. His tachycardia rapidly resolved and he became relatively bradycardic. As he symptomatically improved and was able to tolerate oral fluids, intravenous fluids were weaned.

\section{Test your knowledge}

1. Which of the following are likely differential diagnoses for his renal impairment, given the clinical and laboratory information above? (Please list more than one)

\section{A. Malaria}

B. Rickettsia

C. Typhoid

D. Postinfectious glomerulonephritis (PIGN)

E. Leptospirosis

F. Salmonella

G. Haemolytic-uraemic syndrome

H. Non-steroidal drug-(NSAID)-induced

I. Hypovolaemia secondary to dehydration

J. Dengue

2. Are there any factors in the history that might increase the risk of NSAID-associated toxicity?

3. What is his fractional excretion of sodium (FeNa) at presentation? How does this influence the differential?

Answers are on page 166 